\title{
Determining factors of perceived self-efficacy in information seeking practices through Facebook
}

\author{
Musa Ya'u Giade', M.K. Yanti Idaya Aspura² and A. Noorhidawati ${ }^{2}$ \\ ${ }^{1}$ Bauchi State University Library Gadau, NIGERIA \\ ${ }^{2}$ Department Library and Information Sciences, \\ Faculty of Computer Science and Information Technology, \\ University of Malaya, Kuala Lumpur, MALAYSIA \\ e-mail: Info@bsuglib.info; yanti@um.edu.my (corresponding author); \\ noorhidawati@um.edu.my
}

\begin{abstract}
The paper reports on factors that drive students' perceived self-efficacy in information seeking practices through Facebook. The quantitative study employed random sampling of postgraduate students in a higher learning institution. A total of 354 responses were gathered through a self-reported survey. The findings showed four factors, namely, past performance, other's experience, verbal persuasion and psychological state, have statistically significant correlations with students' perceived self-efficacy in information seeking practices through Facebook. Past performance was found to be the most influential factor followed by other's experience. Verbal persuasion and psychological states were the least influential factor. The outcome of the study contributes to the existing literature particularly on the self-efficacy standpoint in social networking sites (SNS) platform. In addition, the findings are relevant to the field of information seeking behaviour especially in providing evidence that people are searching information using Facebook.
\end{abstract}

Keywords: Self-efficacy; Information behaviour; Information seeking; Facebook; Social media.

\section{INTRODUCTION}

With the advancement of information \& communication technology, information is being shared through different channels, including social media such as Facebook and Twitter. Among the various social networking sites (SNS) on the Internet, Facebook was reported to be the most popular with more than one billion monthly active users (Sinclair and Grieve 2017). SNS allows people to interact and exchange information regardless of their geographically disperse locations. Social media is presently being used as an information seeking medium despite its fundamental purpose that was essentially to support communication and social activities (Head and Eisenberg 2010; Head and Eisenberg 2011; Lenhart et al. 2007; Nicholas et al. 2017; Noorhidawati et al. 2015). This was evident by a few studies reported on the usage of social media as an information seeking tool such as by Abidin, Kiran and Abrizah (2013), Bilgihan, Peng and Kandampully (2014), Hamid et al. (2016), Knight et al. (2015), and Nicholas et al. (2017).

Currently social media is being used as one of the platform to seek information apart from other specific databases, websites or search engines. Information seeking behaviour is a purposive action in searching information normally triggered by a certain need. To satisfy 
this information needs, the seeking process could be influenced by information seekers' behaviour as in their affective, cognitive and physiological states taking consideration of personal, work-life and socio-cultural environment. Most of the time it is difficult to assess what is the best platforms or tools since information seeking process is influenced by the seekers' information needs, their ability to correctly perform the searching task, and type of information being seek. Unlike other common information seeking platforms or tools, social media provides a different experience when conducting the searching process that entails finding information among friends, other people's recommendations, and information based on personal experience among the social media acquaintances. How effective the search process and the searchers capability in seeking information through social media is difficult to assess.

In effectively seeking information through social media, information seekers need to be able to use their skill and ability, taking into consideration their cognitive, emotional, and social behavioural states to fulfill the search goal. Self-efficacy was reported to influence overall human behaviour including thinking pattern, emotions and actions as stated by Kurbanoglu (2003). Perceived self-efficacy is people's perceptions regarding how well they can accomplish particular tasks constituting cognitive behavioural and social skills in certain situations (Bandura 1982). If an individual is confident about their capability to perform a given task, they will be more concerted and determined while they work. In the context of SNS usage, users' perceptions of their abilities towards information retrieval have a significant impact on their performance in the seeking process (Bronstein and Tzivian 2013). Therefore, in understanding this seeking behaviour, perceived self-efficacy theoretical stance was employed in order to investigate people's perceptions on how well they can seek information through SNS platform instituting their cognitive behaviour and social skills. The study was grounded by the Perceived Self-Efficacy theory as the theoretical framework reported by Bandura (2006).

\section{LITERATURE REVIEW}

\section{Information Seeking Practices through Social Media}

Marchionini (1997) defined information seeking as a course of an action initiated by humans' information needs to help them to interact with their environment. To describe this action from the context of web information seeking, Choo and Marton (2003) identified four information seeking styles: (a) undirected viewing - where individuals are exposed to information with no specific informational need in mind; (b) conditioned viewing - where individuals direct viewing to information about selected topics or to certain types of information; (c) informal search - where individuals actively look for information to deepen the knowledge and understanding of a specific issue with relatively limited and unstructured effort; and (d) formal search - where individuals make deliberate or planned efforts to obtain specific information or types of information about a particular issue.

Wilson (2000) stated information seeking behaviour as purposive seeking for information because of a need to satisfy some goals. The search process encompasses not only the action of seeking and using sources, but also the development of thoughts about a topic and the feelings that typically accompany such evolution of thinking (Kuhlthau 1988). This is aligned with a study done by Gkorezis, Kostagiolas and Niakas (2017) who supported information seeking as a sequence of actions to satisfy the various essential needs such as affective, cognitive and physiological, that are generated based on the demands created within a set of contexts such as individual, work-life, socio-cultural and politico-economic environment. According to Myrick (2017) the process of information seeking involves a mixture of 
affective, physical and cognitive human experience, while emotions play a vital role in the information retrieval process. Success in retrieving information is beyond acquiring searching skills and understanding the available information sources. Emotions and other environmental related factors play a significant role in resolving a search outcome. In the context of social media, for example Facebook, users' perceptions of their abilities towards information retrieval have a significant impact on their performance while seeking information (Bronstein and Tzivian 2013). Therefore, in seeking information through social media, users need to be able to use their searching and social skills to fulfill their search goals.

Social media are extensively used across different age groups with various purposes. SNS are among the most popular social media platforms used by college students (Abidin, Kiran and Abrizah 2013; Smith, Rainie and Zickuhr 2011). The common reason of using SNS is for social purpose and to receive update on current news (Head and Eisenberg 2010; Head and Eisenberg 2011; Nicholas et al. 2017). The micro-blogging platforms such as Twitter and media-sharing site such as YouTube are commonly used as sources for news update (AlDaihani 2016; Shah and Cox 2017). Wikipedia is a popular social media site among college students to get an overview of new concepts and additional resources (Abidin, Kiran and Abrizah 2013; Head and Eisenberg 2010). Several studies have revealed adolescents and college students' usage of social media such as Wikipedia for academic and everyday information seeking (Abidin, Kiran and Abrizah 2013; Head and Eisenberg 2011). Despite the existence of different SNS on the Internet, Facebook was reported to be the most commonly used with more than one billion monthly active users (Sinclair and Grieve 2017) and also the most highly used (Ahmad and Qazi 2011). Some common reasons reported in the literature are because it provides a platform to develop and improve users' status and self-esteem, relieve loneliness, create relationship among users and to seek information (Balakrishnan and Shamim 2013). Facebook presents a wide scope of information that is extremely valuable and effective in informing and educating its users. According to Korolevaa and Kane (2016), Facebook is progressively recognized as a trusted mechanism for getting news. Similarly, Adzharuddin and Ramly (2015) state that diversity of information, including news, updates, health awareness, global political status, and climate changes, can be retrieved through Facebook. Additionally, previous studies have signified that information seeking was found to be one of the reasons behind Facebook usage (Adzharuddin and Ramly 2015; Chan Lin and Su 2015; Dhir et al. 2017; Hughes et al. 2012; Kim et. al 2016; Muller, Schneiders and Schafer 2016).

Some research works have studied the use of Facebook for information seeking among students in their academic activities. Roblyer et al. (2010) reported that students used Facebook groups to seek information and preferred to ask their Facebook friends on information related to reference materials and research works instead of going to the library. Amador and Amador (2014) reported that students use Facebook to seek for perspective academic advice and other information on the university academic matters. A study by Chan Lin and Su (2015) showed that students visited university library's Facebook to seek information on current notices and new books promotion. Amador and Amador (2014) conducted a survey investigating students' help seeking and academic advices via Facebook. Their findings showed that student's use Facebook to seek for perspective academic advice and information on the university academic matters. Equally, the findings revealed that students considered the use of SNSs as beneficial in facilitating them in information seeking and are more prepared to interact electronically with higher-education personnel. Park, Kee and Valenzuela (2009) conducted a survey on social media use and gratification. Their findings signified that students gather information through Facebook 
Giade, M. Y., Yanti Idaya Aspura, M.K. \& Noorhidawati, A.

groups on political and civil participation such as entertainment, socialization, self-status seeking.

\section{Self-efficacy and Its Application in Information Seeking Practices through Social Media}

Stajkovic and Luthans (1998) stated that self-efficacy was recognized to have a positive influence on performance in various contexts. This includes performance assessment of information seeking practices from the theoretical lens of self-efficacy theory as stated by Rains (2008), Bronstein (2014), and Deng and Liu (2017). According to Kurbanoglu (2003), self-efficacy can influence the overall human behaviour including their thought pattern, emotions and actions. Perceived self-efficacy entails people's perceptions regarding how well they can perform and execute constituting cognitive behavioural and social skills to deal with day-to-day situations (Bandura 1982). If users are certain or confident about their capability to solve a problem or performing a given task, they will be more concentrated and determined while they work.

According to Bandura (2006), people generated their self-efficacy beliefs by formulating information obtained from the following four major sources of efficacy beliefs:

(a) Past performance: The most well-known of all sources of self-efficacy are past performances of efficacy, also called mastery experience. It was described as interpreted results of individual's previous performance. Individual who has involved in activities and tasks translated the outcomes of their activities. The individual then apply the translated outcome to form beliefs on their abilities to involve in consequent activities or tasks, and act in accord with the beliefs generated (Zhu et. al 2011).

(b) Other's experiences: It is also known as vicarious experiences. Self-efficacy can be partly determined by seeing other people succeeding on a given task. Bandura (1997) reported that when people cannot continually have sufficient means of estimating their capabilities, they would relate their abilities to others.

(c) Verbal persuasion: Individuals usually obtain information in which affirm and convince them that they can perform an action. It is a straightforward to construct and persevere a sense of efficacy particularly under complex conditions if important people (others) express their faith and confidence in individual's capabilities than if they express some doubts (Bandura 1997).

(d) Physiological states: People generate efficacy information from their physiological and emotional states. Symptoms and emotions such as tension, stress reactions, anxiety and confusion can be easily interpreted as signs of failure and weakness. A positive physiological state extends individual's self-efficacy while negative physiological state weakens it (Bandura 1997).

Self-efficacy judgment in social media originated from the following four elements: (a) perceived social media skill; (b) perceived confidence in individual ability to find information online successfully; (c) average of social media composition; and (d) the level of social media content of consumption. Hocevar, Flanagin, and Metzger (2014) in their study found that an individual's Internet self-efficacy is generally dissimilar from individuals' social media efficacy and these two notions should be separated. Therefore, individuals' self-efficacy in social media is based on individual's actual level of social media gratified consumption, information production, perceived social media skill, and individuals' confidence in their own ability to find online information successfully.

Hocevar, Flanagin and Metzger (2014) extended social media self-efficacy to information seeking by investigating the correlation between online information evaluation and social 
media self-efficacy. Studies on Facebook self-efficacy mostly focused on Facebook usage and affordance for career development, emotional dependence on Facebook and academic use of Facebook self-efficacy. Argyris and Xu (2016) conducted a study on college students' selfefficacy improvement through Facebook in relation to their career development. The findings reported two factors that influence the career development self-efficacy in Facebook namely vicarious experience (indirect experience) and social persuasion. Naeemi and Tamam (2017) reported how emotional dependence on Facebook correlates with psychological well-being. The study surveyed students form upper secondary schools and investigated emotional dependence as a mediating effect on self-efficacy. The finding indicated that emotional dependence on Facebook has a negative effect on students' psychological wellbeing. The authors concluded that high-level of self-efficacy did not decrease the negative impact of emotional dependence on students' psychological wellbeing

Research on perceived self-efficacy in information seeking practices through social media is an emerging area. Several studies have been reported on social media self-efficacy but none focusing on information seeking practices. The usage of social media platform has now been extended to seek information, besides its function for social communication. However, the effectiveness of social media as an information seeking platform or tool is difficult to assess. One method of assessment could be done through an investigation on how people perceive self-efficacy in information seeking through Facebook. Thus, this study was conducted with the intention to address this research gap in the existing literature, concerning self-efficacy perceptions of the students in their information seeking practices based on the four sources of self-efficacy information as originally proposed by Bandura (1997). It employed the four major sources of efficacy beliefs as constructs in investigating factors that influence selfefficacy of students when seeking information in the social media environment, particularly in the context of Facebook.

\section{OBJECTIVE AND METHOD}

The main objective of this study was to identify factors that influence perceived self-efficacy of information seeking practices through Facebook. The following research question is addressed: What are the factors that influence perceived self-efficacy of information seeking practices through Facebook? In order to answer the research question, the following hypotheses were postulated:

H1. Past performance has a statistically significant relationship with perceived self-efficacy of information seeking practices through Facebook.

H2. Other's experience has a statistically significant relationship with perceived self-efficacy information seeking practices through Facebook.

H3. Verbal persuasion has a statistically significant relationship with perceived self-efficacy information seeking practices through Facebook.

H4. Psychological state has a statistically significant relationship with perceived self-efficacy information seeking practices through Facebook.

This study employed a quantitative method. The survey instrument was adapted from the works of Bronstein and Tzivian (2013) and Asghar (2015). The instrument was developed 
based on the following variables: (a) self-efficacy; (b) past performance; (c) other's experience; (d) verbal persuasion; and (e) psychological states. A five-point Likert scale was used indicating 1=Strongly Disagree, 2=Disagree, 3=Undecided, 4=Agree, 5=Strongly Agree.

The questionnaire was disseminated to postgraduate students at a research-intensive university in Kuala Lumpur. The population size was estimated to be around 13,200. Based on Krejcie and Morgan (1970), a sample size of 370 was recommended with 95\% confidence level. The questionnaires were printed out and administered to the Institute of Graduate Studies for the duration of two months. A total of 354 responses were gathered resulting in a 94.4 percent response rate. The data was analyzed using Statistical Product and Service Solutions (SPSS), and non-parametric tests Spearman's Rho correlation analysis was conducted to test the hypotheses.

\section{Validity and Reliability of the Research Instrument}

A pilot study was conducted with 20 postgraduate students. Participants were contacted and asked if they were willing to fill-up the questionnaire for a pilot study purpose. Out of the 20 questionnaires distributed, 16 were returned. Based on comments given by several respondents, some amendments were carried out to improve the survey instrument before the full-scale data collection was conducted. Some examples of the amendments were simplifying lengthy questions and rephrasing the questions to provide more clear statement.

Factor analysis and reliability test were conducted to ensure validity and reality of the survey instrument. For the factor analysis to be judged fit, the actual values of the Kaiser-MeyerOlkin (KMO) of sampling adequacy must be between 0.6 and 1.0 and Bartlett's test of Sphericity must be significant at $p<.05$. For the purpose of this study, any item with factor loading of lower than 0.4 were excluded for further analysis. Internal consistency of each scale was measured using Cronbach's alpha. Measurements of reliability are ranged from 0 to 1 , and each scale must exhibit satisfactory reliability with Cronbach's alpha close to or above the recommended value of 0.70 levels.

Table 1 shows the result of KMO and Bartlett's test Sig for all items of the research constructs. None of the items is below the recommended value of 0.6 for $\mathrm{KMO}$ and 0.5 for Bartlett's test Sig. Therefore, no item was excluded for the analysis.

Table 1: Principal Component Analysis of Research Constructs

\begin{tabular}{lccc}
\hline \hline Construct & KMO & Bartlett's test Sig & Percent variance \\
\hline Self-efficacy (DV) & 0.922 & .000 & 59.434 \\
Past performance (IV) & 0.906 & .000 & 55.083 \\
Other's experience (IV) & 0.683 & .000 & 75.580 \\
Verbal persuasion (IV) & 0.737 & .000 & 82.647 \\
Psychological states (IV) & 0.864 & .000 & 71.572 \\
\hline \hline
\end{tabular}

Internal reliability for the scale was tested using Cronbach's alpha. Cronbach's alpha coefficient rules indicates $\alpha>0.90=$ excellent, $>0.80=\mathrm{Good},>0.70=$ Acceptable,$>0.60$ $=$ Questionable, $>0.50=$ Poor,$<0.50=$ Unacceptable (Tavakol and Dennick 2011).

Table 2 presents the results of the reliability testing of all the dependent and independent variables. All five constructs have individually reached an alpha of more than 0.80 , which is above the recommended value of 0.70 . 
Table 2: Results of Validity and Reliability Test

\begin{tabular}{|c|c|c|}
\hline & Variables & Factor loading \\
\hline \multicolumn{3}{|c|}{ Self-efficacy: (Cronbach's $\alpha=0.920$ ) } \\
\hline 1 & $\begin{array}{l}\text { When seeking for information I can solve most problems if } \mathrm{i} \text { invest the } \\
\text { necessary effort. }\end{array}$ & .918 \\
\hline 2 & I Keep trying to find what I am Looking for on Facebook even if it take time & 907 \\
\hline 3 & $\begin{array}{l}\text { I feel that in order to know more about a brand or store, I have to like its } \\
\text { Facebook page }\end{array}$ & .913 \\
\hline 4 & I am sure I can Select relevant Information from a results of a search & .916 \\
\hline 5 & $\begin{array}{l}\text { To me liking pages is the only way of getting genuine Information on } \\
\text { Facebook }\end{array}$ & .910 \\
\hline 6 & $\begin{array}{l}\text { The exchange Of Information Offered on Facebook allows me answer } \\
\text { personal issues effectively }\end{array}$ & .910 \\
\hline 7 & I can usually find information I need on Facebook & .908 \\
\hline 8 & I believe that Facebook provides me information on many subjects & .908 \\
\hline 9 & $\begin{array}{l}\text { I use Facebook to post questions because Facebook users (e.g., friends, } \\
\text { group members etc.) provide me with better answers }\end{array}$ & .914 \\
\hline 10 & $\begin{array}{l}\text { My searching skills make it easier for me to locate genuine Information on } \\
\text { Facebook }\end{array}$ & .909 \\
\hline \multicolumn{3}{|c|}{ Past performance: (Cronbach's $\alpha=0.896$ ) } \\
\hline 1 & Facebook keep me informed about the lives of friends and family members & .891 \\
\hline 2 & Facebook help me find answers to personal problems & .881 \\
\hline 3 & Facebook make me learned about a topic i am not familiar with & .881 \\
\hline 4 & I have a good time reading posts shared on Facebook & .886 \\
\hline 5 & I use Facebook to See News/Cool/photos/Photo-Albums/videos & .880 \\
\hline 6 & $\begin{array}{l}\text { In general, I read news, scientific facts or inspirational quotes shared on } \\
\text { Facebook because I find them Informative }\end{array}$ & .881 \\
\hline 7 & $\begin{array}{l}\text { Facebook group/pages keep me informed about products, services and } \\
\text { trends }\end{array}$ & .884 \\
\hline 8 & To me reading Facebook feed is Informative & .878 \\
\hline 9 & I do not find informative posts on Facebook & .897 \\
\hline \multicolumn{3}{|c|}{ Other's experience: (Cronbach's $\alpha=0.837$ ) } \\
\hline 1 & I can search for information faster than other people & .744 \\
\hline 2 & I seem to know more about searching for information than other people & .700 \\
\hline 3 & $\begin{array}{l}\text { I understand how to search for information better than most of my } \\
\text { colleagues }\end{array}$ & .865 \\
\hline \multicolumn{3}{|c|}{ Verbal persuasion: (Cronbach's $\alpha=0.894$ ) } \\
\hline 1 & My colleagues at School think that I am good at searching for information & .744 \\
\hline 2 & My colleagues seek my help when searching for information & .700 \\
\hline 3 & My friends and family think that I am good at searching for information & .865 \\
\hline \multicolumn{3}{|c|}{ Psychological states: Cronbach's $\alpha=0.898$} \\
\hline 1 & I enjoy searching for information & .874 \\
\hline 2 & I feel energized when I am searching for information & .872 \\
\hline 3 & I think looking for information is relaxing & .875 \\
\hline 4 & Searching for information makes me feel good & .862 \\
\hline 5 & Searching for information can be frustrating & .896 \\
\hline
\end{tabular}

\section{RESULT}

\section{Demographic Information}

Out of 349 responses (with 5 missing value), majority of the respondents were female $(57.3 \%, n=203)$ and $41.2 \%(n=146)$ were male. Fairly even responses were gathered from both Sciences $(52.1 \%, n=182)$ and Non-science $(47.9 \%, n=167)$ fields. The highest responses were coming from Faculty of Science indicated by 11.3 percent $(n=40)$ followed by Faculty 
Giade, M. Y., Yanti Idaya Aspura, M.K. \& Noorhidawati, A.

of Computer Science and Information Technology $(11.0 \%, n=39)$. The least responses were from Faculty of Economic and Administration (5.4\%, $n=19)$.

\section{Hypotheses Testing}

H1. Past performance has statistically significant relationship with perceived self-efficacy of information seeking practices through Facebook.

The result of running a Spearman rho Correlation test shows that there was a statistically significant relationship between past performance and perceived self-efficacy with Spearman coefficient, $r=.828, p<0.001$ as shown in Table 3. Therefore, Hypothesis $1(H 1)$ is accepted.

Table 3: Past Performance vs. Perceived Self-Efficacy

\begin{tabular}{|c|c|c|c|}
\hline & Spearman's rho & Perceived Self-Efficacy & Past Performance \\
\hline \multirow[t]{4}{*}{ Perceived Self-Efficacy } & Correlation & 1.000 & $.828^{* *}$ \\
\hline & Coefficient & & \\
\hline & Sig. (2-tailed) & & .000 \\
\hline & $\mathrm{N}$ & 354 & 354 \\
\hline \multirow[t]{4}{*}{ Past Performance } & Correlation & $.828 * *$ & 1.000 \\
\hline & Coefficient & & \\
\hline & Sig. (2-tailed) & .000 & \\
\hline & $\mathrm{N}$ & 354 & 354 \\
\hline
\end{tabular}

** Correlation is significant at the 0.01 level (2-tailed).

H2. Other's experience has statistically significant relationship with perceived self-efficacy information seeking practices through Facebook

The result of running a Spearman correlation test indicated there was a statistically significant relationship between other's experiences and perceived self-efficacy with Spearman coefficient, $r=.715, p<0.001$ as shown in Table 4. Therefore, Hypothesis $4(\mathrm{H} 4)$ is accepted.

Table 4: Other's Experience vs. Perceived Self-Efficacy

\begin{tabular}{|c|c|c|c|}
\hline & Spearman's rho & Perceived Self-Efficacy & Other's Experiences \\
\hline Perceived Self- & Correlation & 1.000 & $.715^{* *}$ \\
\hline \multirow[t]{3}{*}{ Efficacy } & Coefficient & & \\
\hline & Sig. (2-tailed) & & .000 \\
\hline & $\mathrm{N}$ & 354 & 354 \\
\hline \multirow[t]{3}{*}{ Other's Experiences } & $\begin{array}{l}\text { Correlation } \\
\text { Coefficient }\end{array}$ & $.715^{* *}$ & 1.000 \\
\hline & Sig. (2-tailed) & .000 & \\
\hline & $\mathrm{N}$ & 354 & 354 \\
\hline
\end{tabular}

** Correlation is significant at the 0.01 level (2-tailed).

H3. Verbal persuasion has statistically significant relationship with perceived self-efficacy information seeking practices through Facebook.

The result of running Spearman correlation test reveal that there was a statistically significant relationship between verbal persuasion and perceived self-efficacy with Spearman coefficient, $r=.715, p<0.001$ as shown in Table 5. Therefore, Hypothesis $3(\mathrm{H} 3)$ is accepted. 
Table 5: Verbal Persuasion vs. Perceived Self-Efficacy

\begin{tabular}{|c|c|c|c|}
\hline & Spearman's rho & $\begin{array}{l}\text { Perceived Self- } \\
\text { efficacy }\end{array}$ & Verbal Persuasion \\
\hline Perceived Self- & Correlation & 1.000 & $.585^{* *}$ \\
\hline \multirow{3}{*}{ Efficacy } & Coefficient & & \\
\hline & Sig. (2-tailed) & & .000 \\
\hline & $\mathrm{N}$ & 354 & 354 \\
\hline \multirow[t]{3}{*}{ Verbal Persuasion } & $\begin{array}{l}\text { Correlation } \\
\text { Coefficient }\end{array}$ & $.585^{* *}$ & 1.000 \\
\hline & Sig. (2-tailed) & .000 & \\
\hline & $N$ & 354 & 354 \\
\hline
\end{tabular}

** Correlation is significant at the 0.01 level (2-tailed).

H4. Psychological state has statistically significant relationship with perceived self-efficacy information seeking practices through Facebook.

The result of running Spearman correlation test indicated there was a statistically significant relationship between psychological states and perceived self-efficacy with Spearman coefficient, $r=.528, p<0.001$ as shown in Table 6. Consequently, Hypothesis $4(\mathrm{H} 4)$ is accepted.

Table 6: Psychological State vs. Perceived Self-Efficacy

\begin{tabular}{|c|c|c|c|}
\hline & Spearman's rho & $\begin{array}{c}\text { Perceived Self- } \\
\text { efficacy }\end{array}$ & Psychological States \\
\hline Perceived Self- & Correlation & 1.000 & $.528^{* *}$ \\
\hline \multirow{3}{*}{ Efficacy } & Coefficient & & \\
\hline & Sig. (2-tailed) & & .000 \\
\hline & $N$ & 354 & 354 \\
\hline \multirow[t]{3}{*}{ Psychological States } & $\begin{array}{l}\text { Correlation } \\
\text { Coefficient }\end{array}$ & $.528 * *$ & 1.000 \\
\hline & Sig. (2-tailed) & .000 & \\
\hline & $\mathrm{N}$ & 354 & 354 \\
\hline
\end{tabular}

** Correlation is significant at the 0.01 level (2-tailed).

\section{DISCUSSION}

This study reports four factors that influence students' perceived self-efficacy of information seeking practices through Facebook, namely past performance, other's experience, verbal persuasion and psychological states, among students in a higher institution. The findings are in agreement with Zhu et al. (2011) who reported past performance as a contributing factor in perceived self-efficacy that forms beliefs about the individual capabilities to engage in consequent activities or tasks and act in accordance with the beliefs generated. Additionally, Calkin (1994), Britner and Pajeres (2006) and Bates and Khasawneh (2007) also reported that past performance was signified proves as the most influential when individuals overcome obstacles or succeed in challenging tasks.

The finding also corresponded with Bronstein (2014), who revealed that other's experience could develop peoples' belief in their ability in accomplishing tasks. Individuals can persuade themselves to accept that they are identically competent or incompetent of executing certain task through observing other people's capabilities in a particular task regardless of its success or failure. Nevertheless, Bandura (2006) stated that other's experience source of information usually has a weaker influence than performance-based information. Individual with low mastery experience or uncertainty on their capabilities, are extra sensible to it. 
The present study found a statistically significant relationship between verbal persuasion and perceived self-efficacy. The finding echoed Bong and Skaalvik (2003) who reported feedback increases self-efficacy. Persuasive information and excess feedback are extremely effective if people who give the information are seen to be reliable and knowledgeable by students, and the information provided is realistic.

Psychological state was found to be the least influential of all factors in perceived selfefficacy. The finding of the present study corresponded with Hasan, Hossain and Islam (2014) who suggested psychological states as the least source of generating efficacy beliefs that people obtain from own physiological and emotional states. Feelings and symptoms like stress, anxiety, tension, excitement and reactions can be translated as signs of weakness and failure.

Above all, participants' perception on how well they can seek information through Facebook is influenced by their past performance in the searching practices using the same platform. Apart from that, seeing other people's experience that succeeded in searching through Facebook also determine their perception. Verbal persuasion as other people demonstrated confidence in participants' capability in searching through Facebook also could influence and affirm their perception towards it. Psychological states could influence participations in their perception depending on the positive or negative emotional states.

\section{CONCLUSION}

This study was conducted to determine factors that influence postgraduate students' perceived self-efficacy in information seeking practices through Facebook. The finding signified four factors that influence perceived self-efficacy of information seeking practices through Facebook namely past performance, other's experience, verbal persuasion and psychological state. The outcome of the study would be significant and could contribute to add the existing literature particularly on the self-efficacy standpoint in SNS platform. Generally, the finding is relevant to the field of information seeking behaviour especially in providing evidence that people are searching information through Facebook apart commonly use it for social communication.

Since the findings were gathered from postgraduate students in a single research university, the generalization of the research findings should be treated with caution. Further study could be conducted to a larger population with inclusion of other possible factors including cognitive, affective and psychomotor to provide better understanding of the issue. Future study could include various context of information seeking needs including everyday life information seeking, health information seeking, and religious information seeking to name a few since social media is used mainly for daily life information seeking.

\section{ACKNOWLEDGEMENT}

This research received no specific grant from any funding agency in the public, commercial, or not-for profit sectors. 


\section{REFERENCES}

Abidin, I.M., Kiran, K. and Abrizah, A. 2013. Adoption of public library 2.0: Librarians' and teens' perspective. Malaysian Journal of Library \& Information Science, Vol. 18, no. 3: 75-90.

Adzharuddin, N.A. and Ramly, N.M. 2015. Nourishing healthcare information over Facebook. Procedia - Social and Behavioral Sciences, Vol. 172, no. 27: 383-389. Available at: https://doi.org/10.1016/j.sbspro.2015.01.384.

Al-Daihani, S. 2016. Students' adoption of Twitter as an information source: An exploratory study using the Technology Acceptance Model. Malaysian Journal Of Library \& Information Science, Vol. 21, no. 3: 57-69.

Amador, P. and Amador, J. 2014. Academic advising via Facebook: Examining student help seeking. Internet and Higher Education, Vol. 21: 9-16. Available at: https://doi.org/10.1016/j.iheduc.2013.10.003.

Argyris, Y.E. and Xu, J. 2016. Enhancing self-efficacy forcareer development in Facebook. Computer in Human Behavior, Vol. 55: 921-931 Available at: http://doi.org/chb.2015.10.023.

Asghar, H.M. 2015. Measuring Information Seeking through Facebook: Scale development and initial evidence of Information Seeking in Facebook Scale (ISFS). Computers in Human Behavior, Vol. 52: 259-270. Available at: https://doi.org/10.1016/j.chb.2015.06.005.

Balakrishnan, V. and Shamim, A. 2013. Malaysian Facebookers: Motives and addictive behaviours unraveled. Computers in Human Behavior, Vol. 29, no. 4: 1342-1349. Available at: https://doi.org/10.1016/j.chb.2013.01.010.

Bandura, A. 1982. Self-efficacy mechanism in human agency. American Psychologist, Vol. 37, no. 2: 122-147.

Bandura, A. 1997. Self-efficacy: The Exercise of Control. New York: Freeman.

Bandura, A. 2006. Guide for constructing self-efficacy scales. In F. Pajares \& T. Urdan (Eds.), Self-efficacy beliefs of adolescents, Vol. 5: 307-337. Greenwich, CT: Information Age Publishing.

Bates, R. and Khasawneh, S. 2007. Self-efficacy and college students' perceptions and use of online learning systems. Computers in Human Behavior, Vol. 23, no.1: 175-191.

Bilgihan, A., Peng, C. and Kandampully, J. 2014. Generation Y's dining information seeking and sharing behavior on social networking sites: An exploratory study. International Journal of Contemporary Hospitality Management, Vol. 26, no. 3: 349-366. Available at: http://doi.org/10.1108/IJCHM-11-2012-0220

Bong, M. and Skaalvik, E. M. 2003. Academic self-concept and self-efficacy: How different are they really?. Educational Psychology Review, Vol. 15: 1-40. Available at: http://dx.doi.org/10.1023/A:1021302408382.

Britner, S.L. and Pajares, F. 2006. Sources of science self-efficacy beliefs of middle school students. Journal for Research in Science Teaching, Vol. 43, no. 5: 485-499.

Bronstein, J. 2014. The role of perceived self-efficacy in the information seeking behavior of library and information science students. Journal of Academic Librarianship, Vol. 40, no. 2: 101-106. Available at: https://doi.org/10.1016/j.acalib.2014.01.010.

Bronstein, J. and Tzivian, L. 2013. Perceived self-efficacy of library and information science professionals regarding their information retrieval skills. Library and Information Science Research, Vol. 35, no. 2: 151-158.

Calkin, L. 1994. The art of teaching writing. Portsmouth: Heinemann.

Chan, L.J., and Su, Y.R. 2015. Assessing information needs and interaction needs for library Facebook. Procedia - Social and Behavioral Sciences, Vol. 191, no. 2: 319-322. Available at: https://doi.org/10.1016/j.sbspro.2015.04.703. 
Choo, C.W. and Marton, C. 2003. Information seeking on the web by women in IT professions. Internet Research: Electronic Networking Applications and Policy, Vol. 13, no. 4: $267-280$.

Deng, Z., and Liu, S. 2017. Understanding consumer health information-seeking behavior from the perspective of the risk perception attitude framework and social support in mobile social media websites. International Journal of Medical Informatics, Vol. 105: 98109. Available at: http://doi.org/10.1016/j.ijmedinf.2017.05.014

Dhir, A., Khalil, A., Lonka, B. and Tsai, C.C. 2017. Do educational affordances and gratifications drive intensive Facebook use among adolescents?. Computers in Human Behavior, Vol. 68: 40-50.

Hasan, M.Z., Hossain, M.T. and Islam, M.A. 2014. Factors affecting self-efficacy towards academic performance: A study on polytechnic students in Malaysia. Advances in Environmental Biology, Vol. 8/9, no. 4: 695-705.

Head, A.J. and Eisenberg, M.B. 2010. How today's college students use Wikipedia for courserelated research. First Monday, Vol. 15, no. 3. Available at: http://journals.uic.edu/ojs/index.php/fm/article/view/28302476/

Head, A.J. and Eisenberg, M.B. 2011. How college students use the Web to conduct everyday life research. First Monday, Vol. 16, no. 4. Available at: http://journals.uic.edu/ojs/index.php/fm/article/view/3484/2857

Hocevar, T.P., Flanagin, A.J. and Metzger, M.J. 2014. Social media self-efficacy and Information evaluation online. Computers in Human Behavior, Vol. 39: 254-262.

Hughes, D.J., Rowe, M., Batey, M., and Lee, A. 2012. A tale of two sites: Twitter vs. Facebook and the personality predictors of social media usage. Computers in Human Behavior, Vol. 28, no. 2: 561-569. Available at: https://doi.org/10.1016/j.chb.2011.11.001

Kim, D. H., Sung, Y. H., Lee, S. Y., Choi, D. and Sung, Y. 2016. Are you on timeline or news feed? the roles of Facebook pages and construal level in increasing ad effectiveness. Computers in Human Behavior, Vol. 57: 312-320. Available at: https://doi.org/10.1016/j.chb.2015.12.031

Korolevaa, K. and Kane, G.C. 2016. Relational affordances of information processing on Facebook. Information and Management, Vol. 54, no. 5: 560-572. Available at: http://dx.doi.org/10.1016/j.im.2016.11.007.

Krejcie, R.V. and Morgan, D.W. 1970. Determining sample size for research activities. Educpsychol Measurement, Vol. 30: 607-610. Available at: https://doi.org/10.1177/001316447003000308.

Kuhlthau, C.C. 1988. Developing a model of the library search process: Cognitive and affective aspects. $R Q$. Vol. 28, no. 2:232-242.

Kurbanoglu, S. 2003. Self-efficacy: A concept closely linked to information literacy and lifelong learning. Journal of Documentation. Vol. 59, no. 6: 635-646. Available at: https://doi.org/10.1108/002204.

Lenhart, A., Madden, M., Macgill, A. R. and Smith, A. 2007. Teens and social media. Available at: http://www.pewinternet.org/2007/12/19/teens-and-social-media/

Marchionini, G. 1997. Information seeking in electronic environments. New York: Cambridge University Press.

Muller, P., Schneiders, P. and Schafer, S. 2016. Appetizer or main dish? Explaining the use of Facebook news posts as a substitute for other news sources. Computers in Human Behavior, Vol. 65: 431-441. Available at: https://doi.org/10.1016/j.chb.2016.09.003.

Myrick, J.G. 2017. The role of emotions and social cognitive variables in online health information seeking processes and effects. Computers in Human Behavior, Vol. 68: 422433. Available at: https://doi.org/10.1016/j.chb.2016.11.071.

Naeemi, S. and Tamam, E. 2017. The Relationship Between Emotional Dependence on Facebook and Psychological Well-Being in Adolescents Aged 13-16. Child Indicators 
Research, Vol. 10, no. 4: 1095-1106. Available at: https://doi.org/10.1007/s12187-0169438-3.

Nicholas, D., Boukacem-Zeghmouri, C., Rodríguez Bravo, B., Xu, J., Watkinson, A., Abrizah, A., Herman, E. and Swigon, M. 2017. Where and how early career researchers find scholarly information. Learned Publishing, Vol. 30, no. 1: 19-29.

Nicholas, D., Watkinson, A., Boukacem-Zeghmouri, C., Rodríguez-Bravo, B., Xu, J., Abrizah, A., Świgoń, M. and Herman, E. 2017, Early career researchers: Scholarly behaviour and the prospect of change. Learned Publishing, Vol. 30, no. 2:157-166.

Noorhidawati, A., Chu, S.K.W., Rajagopal, S., Wan, W.T.A. and Yeung, K.M. 2015. Exploring libraries effort in inclusion and outreach activities using social media. LIBRI (International Journal of Libraries and Information Services), Vol. 65, no. $1: 34-47$.

Gkorezis, P., Kostagiolas, P. and Niakas, D. 2017. Linking exploration to academic performance: The role of information seeking and academic self-efficacy. Library Management, Vol. 38, no. 8/9: 404-414. Available at: https://doi.org/10.1108/LM-022017-0021.

Hamid, S., Bukhari, S., Ravana, S. D., Norman, A. A. and ljab, M. T. 2016. Role of social media in information-seeking behaviour of international students: A systematic literature review. Aslib Journal of Information Management, Vol. 68, no. 5: 643-666.

Knight, E., Intzandt, B., MacDougall, A. and Saunders, T. J. 2015. Information seeking in social media: a review of YouTube for sedentary behavior content. Interactive Journal of Medical Research, Vol. 4, no. 1: e3. Available at: http://doi.org/10.2196/ijmr.3835

Park, N., Kee, K.F. and Valenzuela, S. 2009. Being immersed in social networking environment: Facebook groups, uses and gratifications, and social outcomes. CyberPsychology and Behavior, Vol. 12, no. 6: 729-733. Available at: https://doi.org 10.1089/cpb.2009.0003

Rains, S. A. 2008. Seeking health information in the information age: The role of Internet self-efficacy. Western Journal of Communication, Vol. 72, no. 1: 1-18. Available at: http://doi.org/10.1080/10570310701827612

Roblyer, M. B., McDaniel, M., Webb, M., Herman, J. and Witty, J.V. 2010. Findings on Facebook in higher education: A comparison of college faculty and student uses and perceptions of social networking sites. Internet and Higher Education, Vol. 13, no. 3: 134140. Available at: https://doi.org/10.1016/j.iheduc.2010.03.002.

Shah, Nordiana Ahmad K. and Cox, Andrew M. 2017. Uncovering the scholarly use of Twitter in the academia: Experiences in a British University. Malaysian Journal of Library \& Information Science, Vol. 22, no. 3: 93-108.

Sinclair, T.J. and Grieve, R. 2017. Facebook as a source of social connectedness in older adults. Computer in Human Behavior, Vol. 66: 363-369. Available at: https://doi.org/10.1016/j.chb.2016.10.003

Smith A., Rainie L. and Zickuhr K. 2011. Report: College students and technology. Pew Research Centre. Vol. $19 . \quad$ Available at: http://www. pewinternet.org/2011/07/19/college-students-and-technology.

Stajkovic, A.D. and Luthans, F. 1998. Self-efficacy and work-related performance: a metaanalysis. Psychological Bulletin, Vol. 124, no. 2: 240-261.

Tavakol, M. and Dennick, R., 2011. Making sense of Cronbach's alpha. International Journal of Medical Education, Vol. 2: 53.

Wilson, T. D. 2000. Human information behavior. Informing Science, Vol. 32, no. $2: 49-55$.

Zhu, Y.Q., Chen, L.Y., Chen, H.G. and Chern, C.C. 2011. How does Internet information seeking help academic performance? - The moderating and mediating roles of academic self-efficacy. Computers and Education, Vol. 57, no. 4: 2476-2484. Available at: https://doi.org/10.1016/j.compedu.2011.07.006. 